\title{
Austrian Measures for Prevention and Control of the Plague Epidemic Along the Border With the Ottoman Empire During the $18^{\text {th }}$ Century
}

\author{
Boro Bronza ${ }^{1}$
}

\section{ABSTRACT}

Throughout centuries, policies of states in the Western Balkan region were largely shaped in accordance with the infection outbreaks and consequences of plague epidemics. Austrian policy was not out of the line in this context, so the general aspects of dealing in organisation of military border with the Ottoman Empire were always crucially connected with the reactions towards epidemics. Especially in the 16th and 17th centuries, Austria battled hard to stop expansion of epidemics that during those times mainly fluxed in from the side of the Ottoman Empire. The decisive change came in the 18 th century. During this period, the Austrian reaction to plague outbursts at the area of south-eastern Europe was already a product of general rise of sanitary standards in western European regions, where attempts for implementation of some of newest qualities in perception of the quarantine requirements and medicine applications met with complex aspects of life in a turbulent area of military border. Efficiency of measures was instant and sustainable in the long term.

Key words: plague, Austrian Empire, Ottoman Empire, epidemics, quarantine.
(1) Department of History, Faculty of Philosophy, University of Banja Luka, the Republic of Srpska, Bosnia and Herzegovina.

Correspondence:

BORO BRONZA

E: boro.bronza@ff.unibl.org

\section{ARTICLE INFO}

Received: 3 October 2019 Revision received: 11 November 2019 Accepted: 12 November 2019
Some crucial movements in the aspect of political shaping of south-eastern Europe during last several millennia were firmly connected with the directions and timing of plague epidemics. Such patterns have also been pretty much present at the area of western Balkans throughout era of confrontations between the Habsburgs (the Austrians) and the Ottomans (the Turks), especially in the $17^{\text {th }}$ and $18^{\text {th }}$ century. Special breakthrough in the taming of the rage in the destructive epidemics came in the $18^{\text {th }}$ century, when the Austrian side started the series of measures that in the long term completely eliminated plague as significant factor in the political calculations and also as essential threat to the regions next to Ottoman border.

\section{The significance of plague outbreaks}

The penetration of the Habsburgs into the interior of the Bosnian Pashalik (the territory gov- erned by pasha) was to some extent prevented by the plague epidemics, which were relatively frequent in the Pashalik area during the 17th century. News from Dubrovnik on the events in Bosnia throughout the Great Vienna War (16831699) between the Austrians and the Ottomans also reported on the details of the plague outbreaks. In Bosnia, the epidemics raged constantly in the period 1686-1690, and then again in 1694. ${ }^{1}$ Probably one such epidemic was the cause of the stalemate of a large and very successful offensive of the Austrian army, which, during the winter of $1688 / 89$, moved from northern Serbia, ${ }^{2}$ through Zvornik and Srebrenica (eastern Bosnia), to the plateau of Romanija, and in fact to the entrance to Sarajevo. ${ }^{3}$

Plague epidemics were very common throughout the 18th century in the Ottoman Empire. Out of a total of 100 years of that century, the plague itself was present in Istanbul for as long as 64

Copyright $\odot 2019$ Bronza. This is an open access article distributed under the Creative Commons Attribution License (CC BY), which permits unrestricted use, distribution, and reproduction in any medium, provided the original work is properly cited. 
years. ${ }^{4}$ Istanbul, as the largest city and largest meeting point of the Empire, was the destination where epidemics were most common. Other parts of the Ottoman state were affected by epidemics at very different frequencies. In Wallachia and Moldova, the plague has raged for a total of 45 years, in Serbia, Bosnia and Herzegovina for 41 years, in Bulgaria for 18 years, and in Mesopotamia for only 4 years. ${ }^{4}$ At the beginning of the century, the plague was still present in western and central Europe. It was raided in parts of the Habsburg Monarchy between 1700 and 1714. New epidemics occurred in 1726, 1729-1732, $1738-1739$ and $1743 .{ }^{5}$ With the passage of the $18^{\text {th }}$ century, the number of epidemics was decreasing. The development of a sanitary cordons at the border with the Ottomans was of great importance for such an outcome.

Quarantine stations, as a system to prevent the spread of the plague infection, existed in some coastal cities, such as Dubrovnik, as early as the late Middle Ages. Since the plague infection at the territory of the Ottoman Empire was largely viewed through the prism of a religious fatalism, implying that epidemics were seen as a "divine punishment" against which nothing could be done, there was no fundamental change during the $18^{\text {th }}$ century in relation to the most dangerous infectious disease at those times. ${ }^{6}$ The Habsburg Monarchy was greatly affected by epidemics, as it shared a long land border with the Ottoman Empire. Therefore, one of the most important forms of the Habsburg border organisation according to the Ottomans was the establishment of an efficient sanitary cordon. During the $18^{\text {th }}$ century, the military landscape of the Habsburg Monarchy stretched from Bukovina to the Adriatic Sea, approximately 1,900 kilometres long (Figure 1). The depth of its territory varied from 15 to 50 kilometres. The total area of this specific military zone was 47,400 square kilometres. In addition to all its functions related to the defensive and offensive plans of the Ottoman Empire, the accumulation of manpower for military purposes, the transmission of trade activities, etc was significant. The military landscape served as a sanitary "shield" for the inland Austrian regions.

The institutional development of a system to prevent the spread of the plague epidemic to

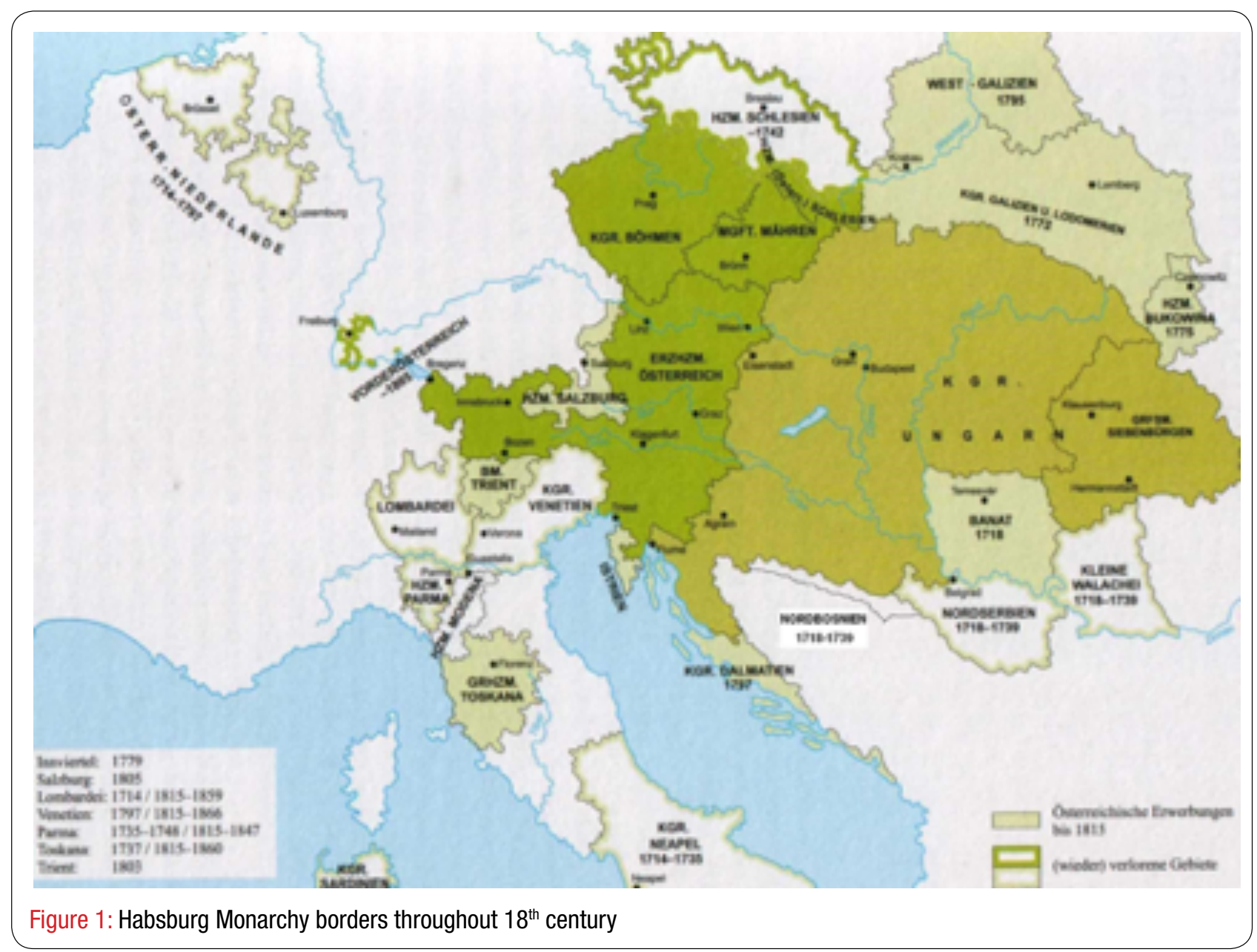


the Habsburg Monarchy ran through the whole of the $18^{\text {th }}$ century.

As early as during the reign of Leopold I (16581705), the rule was that all forms of traffic with the Ottoman Empire should be interrupted during the plague epidemic. ${ }^{6}$ The first official regulatory document on border behaviour to prevent the spread of the epidemic was the so-called "Plague patent" ("Pestpatent") from 1710. This action was not yet strictly of sanitary character and not entirely successful, as the Habsburg countries were also affected by the plague epidemic of 1713-1715. In Vienna in 1718, on the occasion of the previous epidemic, the Court Sanitary Commission (Sanitäts Hofkomission) was established, and for the first time medical personnel were deployed at the border. ${ }^{4}$ However, the real beginning of the sanitary cordon was linked to the year 1728 and the patent for the construction of a quarantine system, which was issued by Charles VI on 22 October that year. From that moment on, the Military Frontier functioned as a "living wall" towards Ottoman Empire.

In accordance with the patent of 1728 , on 3 Oc-

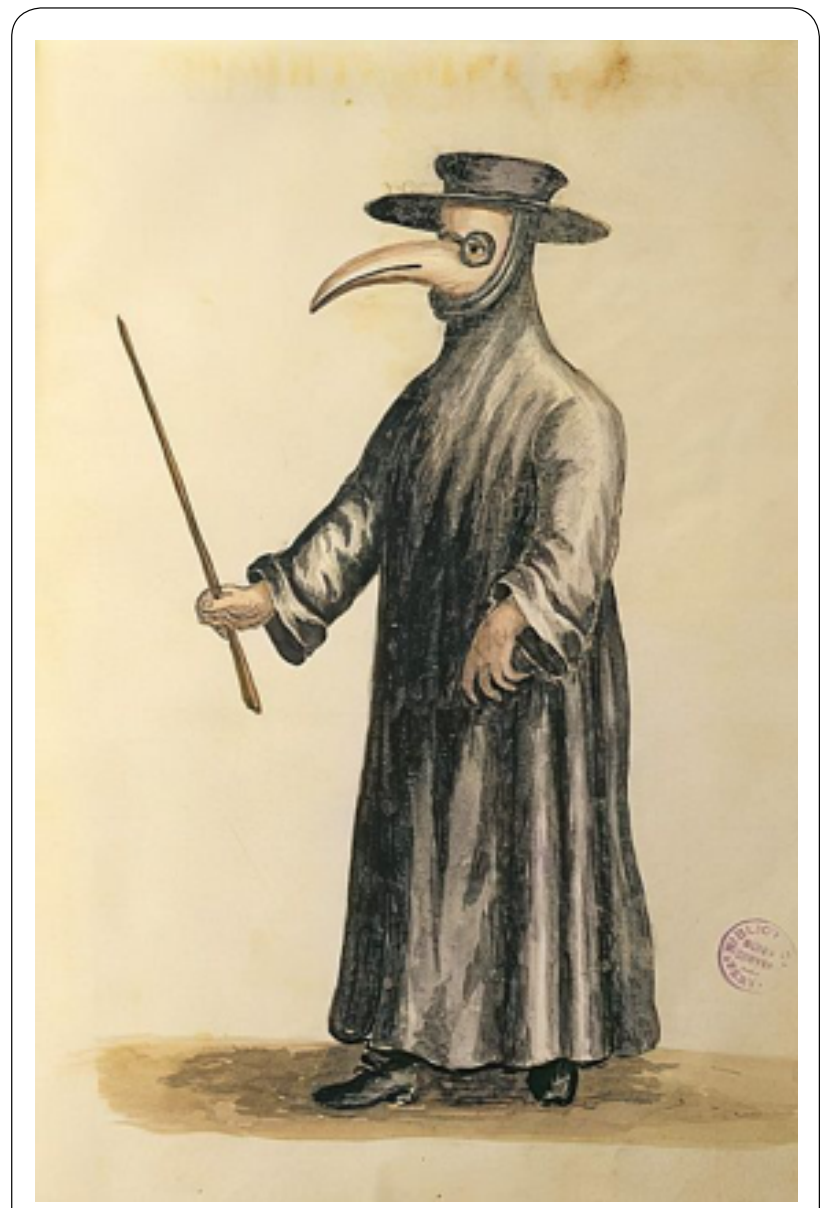

Figure 2: The Plague Doctor $17^{\text {th }}-18^{\text {th }}$ century tober 1731, a rule on quarantine and hygienic behaviour at the border was also issued ("Contumaz- und respective Reinigungs-Ordnung"). ${ }^{6}$

That rule strictly prescribed a system of behaviour at the border. In the quarantine stations there had to be one lieutenant with 30 horsemen and three border guards. In each quarantine, there had to be one doctor (Figure 2), who examined the people coming to the border crossings, with whom the quarantines were mandatory. The mandatory implementation of these rules, which entailed structural reform of the Habsburg border system and large accompanying investments, could not be implemented quickly and easily.

During the reign of Charles VI, wars were the primary component of the operation of the Habsburg court in the southeast, so that there was no time or resources to concentrate on building a sanitary cordon. The government of the Austrian Empress Maria Theresa intended from the beginning to concentrate more on the formation of a system of protection at the border, but even in the period 1740-1763 it was also occupied by major wars in the north and west. This is why the creation of a dense quarantine system in the true sense began only after 1763 . Special sanitary commissions were established, with their headquarters in Karlovac, Zagreb, Osijek, Timisoara and Sibiu. Lazarettes, as institutions for the accommodation of patients directly related to quarantines, were located along the border in places such as Rudenovac, Slunj, Maljevac, Kostajnica and Brod. The 'rastels', which used to be rehabilitation centres, were located along the border in Gradiška, Kobaš and Mitrovica. ${ }^{4}$ Quarantine and lazarette in Kostajnica (northern Bosnia) played a special role in view of the heavy traffic of people, especially during migration. The importance of quarantine in Kostajnica was reflected primarily in the fact that Kostajnica was located on the Sarajevo-Banja Luka-Zagreb-Ljubljana-Verona-Milano trade route. ${ }^{4}$

\section{Centralisation of institutions}

Special regulations have been made in Vienna to schedule the obligations of border guards who were in service at the quarantine stations. According to them, one border guard had to spend exactly 52 days on quarantine, and 49.5 days he had to spend in his regiment, wherever he was. In addition, he was required to spend 48 days in 
military exercises, which in total meant that he had to spend five months a year under arms. For the remaining seven months he was obliged to farm. Under the normal circumstances, the total cadre of sanitary cordons at its $1,900 \mathrm{~km}$ length was 4,000 people. If plague occurred in Istanbul, the number of people hired would increase to 7,000. If the plague were to occur in Wallachia and Moldova or Bosnia and Serbia, or at the borders of the Monarchy, the number of people involved would be 11,000. ${ }^{6}$

In the Bosnian pashalik, plague was quite common during the $18^{\text {th }}$ century. The Austrians have always made every effort to find out whether such epidemics are present in certain areas of Bosnia and Herzegovina. Thus, through Dubrovnik they learned that the plague epidemic had been present in Herzegovina in 1722-1723, and again in $1782-1783 .^{7}$ Austrian spies informed the authorities about the details connected with the outbreak of plague in Bihać and Banja Luka in 1733-1734, and again in 1741-1743.8 The plague outbreak in Bosnia was recorded again in $1787 .{ }^{1}$

One of the most specific points of the Austrian sanitation policy was the determination of the number of days that travellers to Austrian countries had to spend quarantined at the border. In the 1760's the rule was that, at the time of the well-established plague epidemic on the borders of the Monarchy, the mandatory quarantine time had to be 84 days, and in situations where it was only assumed that the plague existed, a stay of 42 days in the quarantine was mandatory. When it was certain that there was no plague, the passengers were quarantined for 21 days. Such strictly formulated hygiene regulations were a good prevention of the spread of the plague, but they drastically reduced mobility at the border, which reflected very poorly on the development of trade. The new sanitary norm of 1770 fixed that quarantine would last 42 days in the case of plague, and in the case of no plague, it would still be 21. Neither was enough to gain trade momentum. It was not until 1785 , on the recommendations of Adam Chenot, a special medical advisor who came from Luxembourg to Vienna, that the quarantine in the plague period was 21 days, in the situation of a presumption of a plague epidemic 10 days, and when the Austrian authorities were sure that there was no plague the quarantine was completely abolished. ${ }^{6}$ This decision allowed for a much more intensive flow of people and goods at the border, which greatly encouraged trade in the years before the new
Austrian-Turkish War of 1788-1791.

The Austrian protection system has proven to be very effective. After its introduction, the plague appeared only in Hungary and Croatia during the great epidemic of $1739-1742 .{ }^{9}$ When the system was fully built, after 1763 , the plague epidemic no longer appeared on the territory of the Habsburg lands. At the same time, the plague epidemic was quite common in the Ottoman Empire, Russia, Poland, Wallachia, Moldova, and Venice until $1785 .{ }^{4}$ This was proof that the system of measures taken by Austria to prevent the spread of a dangerous disease outweighed its neighbours' modest attempts to build their sanitary cordon systems. Some Austrian historians treat the effective actions of the Habsburgs in preventing the spread of the plague epidemic as "saving all of Europe". ${ }^{6}$

\section{Consequences for the trade}

The new dimension of trade with the East also entailed regulating trade with the Bosnian Pashalik, with such regulation also being substantially related to the global perception of human and goods traffic in the area of the new border on the Una and the Sava rivers, especially given the more stringent sanitary measures that increasingly developed within the Military Landscape. On 25 August 1742, the Court of War Council sent a directive to General Quadanji to find the most suitable place at the border for the construction of larger capacity quarantines, which would, in fact, create the conditions for centralisation of border traffic in one location ("... die erbau- und herstellung eines eigenen Contumazhausses zwischen Bosnien und Croathen disseiths der Vuna ohnweith Novi von seithen des Militaris nur nöthig seye, damit $z u$ errichtung sothanen Gebaües ein bequemmen Plaz ausfindig gemacht, und assigniret werde..."). ${ }^{10}$ At that moment, the Council did not have the right information on the quality and quantity of work of the already existing quarantine in Kostajnica. General Quadanji was told that he should first inquire about the details of the quarantine operation in Kostajnica, ${ }^{11}$ in order to be convinced at all of the necessity of building a new quarantine facility, which, roughly, should be located near Novi (north-west Bosnia). In this regard, representatives of the higher directorate of the Slavonian Chamber, Johann Wilhelm Vogt and Johann Paul Passardi, sent a letter from Osijek to the Court Chamber on 31 August 1742, with their opinion on the eventual establishment of the new quarantine. Repre- 
sentatives of the Slavonian Chamber said that the quarantine in Kostajnica is very necessary, especially in the context that the new border is still very vulnerable, especially in the Dubica area ("welcher ratione deren zwischen denen Türckhen in Bosnien und Croathen zu Dubitza annoch schwebenden Graniz-strittigkeithen zu aussmachung der sache sich ehehin alda in Loco befindet... "). ${ }^{10}$ The cost for establishment of a new quarantine was estimated at 4,000 ducats. Due to all of the above, they concluded that the quarantine in Kostajnica was still necessary, and that there was no particular need to build a new quarantine at Novi ("Bey allem deme scheinet es, dass.. die Absicht das erösterte Contumaz Hauss zu Novi errichten zu lassen, nun umb so viellmehr zerfalle, alss eben ein dergleichen Gebaüde alschon zu Kostaniza ohnweith von obigen Orth vorhanden seye..."). ${ }^{10}$

The following year, it was definitely decided to build a new quarantine, but in the immediate vicinity of the old one, in Kostajnica. Quarantine was built on the Balanka River Island. On 21 June 1743, Ban Bacanyi informed the Court of the War Council of Valpovo about the great expenses that were necessary to build the new, huge building, but also about the extraordinary benefits it would bring to the Monarchy. The main engineers for the quarantine construction were Lazzeni and Griesseyssen. The Quarantine looked like a lavish fort. The Ban emphasised that construction was not about aesthetics, but about the quality and purpose of the material, so that the building could last for as long as possible and serve its purpose ("... ein solches Gebaü blos zur wohlfahrt, und sicherheit des landes anzusehen, also auch hieran weiter keine Zierd erforderlich ist, folgends nur dauerhafte, und diensam gute Bau-materialien fürgekehrt..."). ${ }^{10}$ Baron Patačić, the Commander of Kostajnica, made the keynote address on the procurement of the construction materials and all other quarantine-related matters. With the completion of operations, Kostajnica definitely became a key quarantine and border centre on the left bank of the Una and the Sava rivers (Figure 3), which implied that in the following decades its importance in the context of trade traffic has grown tremendously.

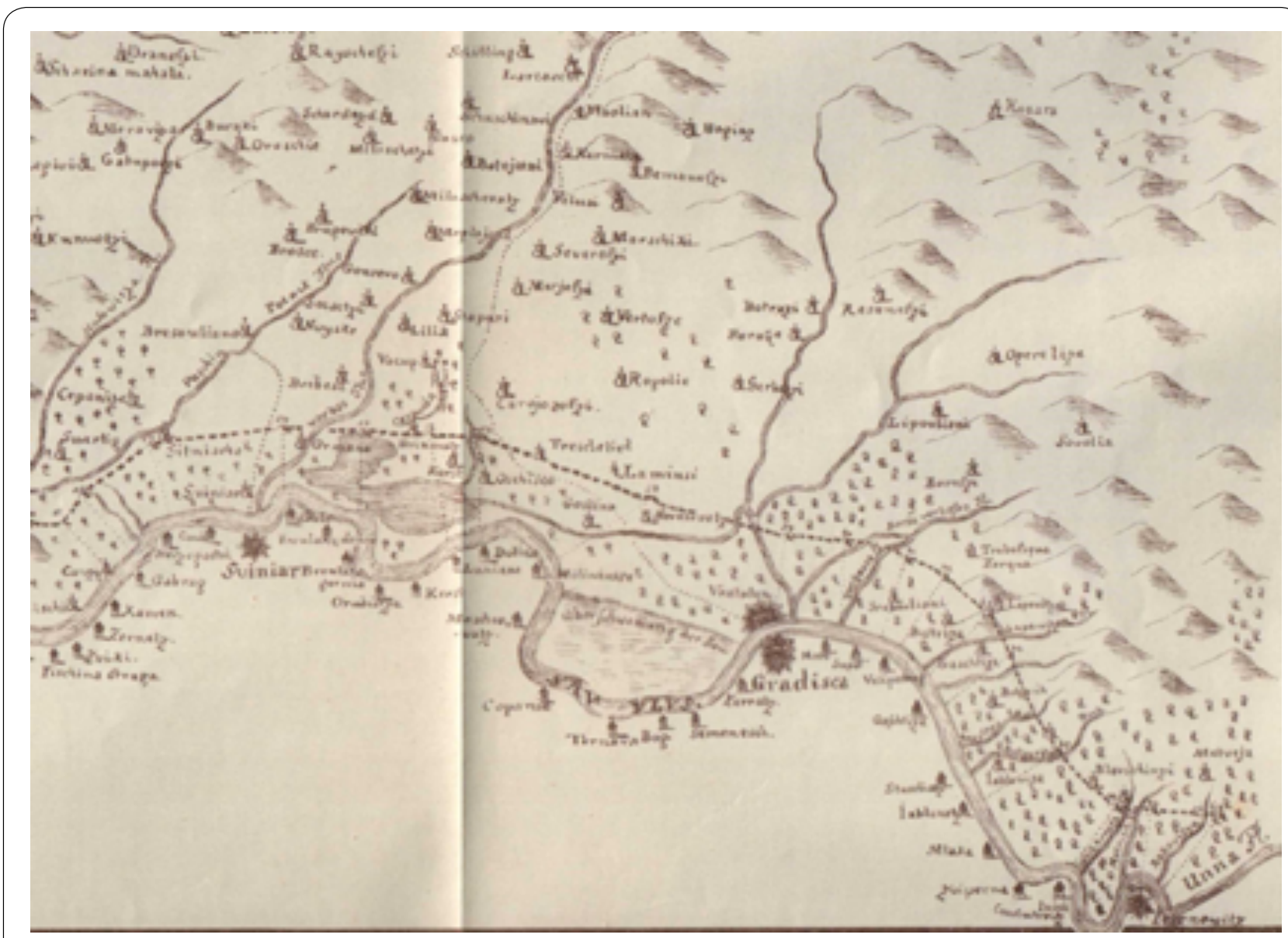

Figure 3: Map from 1725, with the border between the Habsburg Monarchy and the Ottoman Empire at parts of the Una and the Sava (orientation towards south) 
The Kostajnica quarantine was also often visited by the Serbian traders from Sarajevo. Todor Rajović, Jovan Mihadović and Andrija Vuković arrived in the quarantine on 21 December 1754.

There, the quarantine surgeon on duty, Wisinger, concluded that all traders were healthy and that their further journey to the Monarchy did not present a danger in terms of transmitting infectious and other diseases ("Kommen aus der Türkey v[on] Sarajeva der Totor Rayovich, Jovan Mihadovich und Andrea Vukovich, 3 Grichische Handels-leuth; Seynt Gesund befunden."). ${ }^{10}$ The quarantine policy in Kostajnica, by the way, was very strict throughout 1754 , due to the frequent news of the plague epidemics in Bosnia, Serbia and other parts of the Ottoman Empire. ${ }^{12}$ On 28 May, the quarantine surgeon Wisinger informed the Banska Krajina Command that the first news of the spread of the infection from Turkey had arrived in Kostajnica from the Karlovac General's area. The contagion spread across the mainland, south of Novi. This is why particularly tight controls have been established in that part of the border ("Übrigens Habe ich gantz Jüngst zwahr noch per indirectum Ir doch eine Bestättige nachricht erhalten, welcher gestalten man in dem Benachbarten Generalat Carlstatt aus aus dem Türkischen gebieth neuerliche Spuren einer Contagiosen Infection habe, und daher auch schon ein scharfer Cordon an dortigen Granitzen gezogen worden seye..."). ${ }^{10}$ The visitor concluded that it was necessary to establish a frequent patrol system on the left bank of the Una river as well, and to prevent all contact with the other bank in order to prevent infection from spreading in the Banska Krajina area ("Es ist also die Vordorge erfoderen... und Veranstalten, dass an denen Gräntzen des Vuna Flusses auf das fleisigste patroulliret, und alle abseitige communication und postirungen wohl entgegen Zustehen, und solche einzustrecken." ). ${ }^{10}$

This meant that during 1754 not only a strict quarantine (Figure 4) was introduced for the transport of people and livestock, but also for all the merchandise. Several deliveries of cotton coming from Macedonia, then heavily affected by the plague epidemic, as well as tobacco, imported from Bosnia by the traders Ivan Parlo and Todor Jurić, were halted in July ("Es zeichten Ivan Parlo und Thodor Jurich bey mir an, wie dass selbige einigen Vorrath Türkischen blätter Tabak in 6o Cent[ner]s Bestehend in Bossnien erkauft Hätten, und solchen nun gerne Herüber Bringen mögten..."). ${ }^{10}$ The purchase of hay from the Bosnian Pashalik area has been a constant in Austrian trade policy. In the conditions of rigorous regulation of the traffic of people and goods, alternative ways had to be found to maintain the continuity of that essential aspect of trade. On 29 July, the Banska Krajina governor from Petrinja informed Colonel Kleefeld that future hay purchases made it necessary for the Krajina officers to be present with the buyers themselves, and that the Turkish side should oblige its officers to be present with the sellers. When picking up the goods, it was not allowed for Habsburg representatives to come into long contact with the hay sellers from Turkey, or to talk to them for long, but after the goods were taken, they should leave the place of purchase as soon as possible ("... niemand von denen Türkischen Unterthanen mit denen unsrigen Granitzern einen Umgang pflegen, viel weniger einen Handel, und Wandel treibe..."). ${ }^{10}$

The Ottomans were also surprised by the tightening of sanitary criteria at the border. In a letter sent on 15 January 1756, Captain of the fortress in Novi, Rustem-beg Cerić, expressed amazement at the Commander of Kostajnica, Major Kristof Vojković, because the Turkish aga carrying a letter to the Krajina general had to spend 21 days in quarantine ("... tako razumesmo da na Szkeloi vassi pregye y 21 dan daga metnete na Stalliu, Krainszke navade doszada ni billo, koiszu G-dina G-dina Passe sz-lisztma dohodili Age, Tergovichkim putem nehode dabisze vu Stalliu metalli..."). ${ }^{10}$ Since this had not been the case before, the captain sought an explanation. Despite the protests, the Austrian side has been very consistent and rigorous in its approach to the quarantine. During 1756, quarantine and borders were completely closed for travellers from Turkey after any news of the plague epidemic. This also happened on 10 August, when the director of the quarantine, Xaver Anton Natterhürn, issued special regulations on maintaining cleanliness, especially in and around pig holding rooms ("Schwein-ställe"). With a special consternation, Naterhirn referred to the attempts to smuggle six bales of sheepskin from the Bosnian Pasalik at a market in Zagreb. The smuggling was again attempted by boats across the Una river, during the night, with the agreement of some merchants from the Ottoman and Austrian sides. Even Empress Maria Theresa reacted to such quarantine policy disciplines, and in a letter to the Croatian ban from 1 Oc- 
tober 1756 , threatened that all those who would not comply with the quarantine policy would be sentenced to death by crossing the border. ${ }^{10}$

In some cases, Austrian hypocrisy within the framework of the sanitary border policy was evident. Namely, the transitions of the Austrian encroachments into the territory of the Bosnian Pashalik, which also took place on a tentative basis, mostly during the night, regardless of the epidemiological situation in the Ottoman Empire, were not subject to the strict sanitary regulations. Such a case, among others, occurred in 1755, when Dubica's commander, Captain Wollgemuth, sent his spy for information into the interior of the Pashalik ("... zur Einholung der Wahrheit einen Vertratuen Mann in das Türkische abgeschickt..."). ${ }^{10}$

Problems with violations of the sanitary regulations, that is, continuous attempts to smuggle goods for trade, followed the Austrian border-quarantine policy during the 1760's. Then the quarantine director at Kostajnica, Philippus Haller frequently reported to the Banovina authorities about the traffickers' attempts to smuggle fish, iron, tobacco and other articles into the

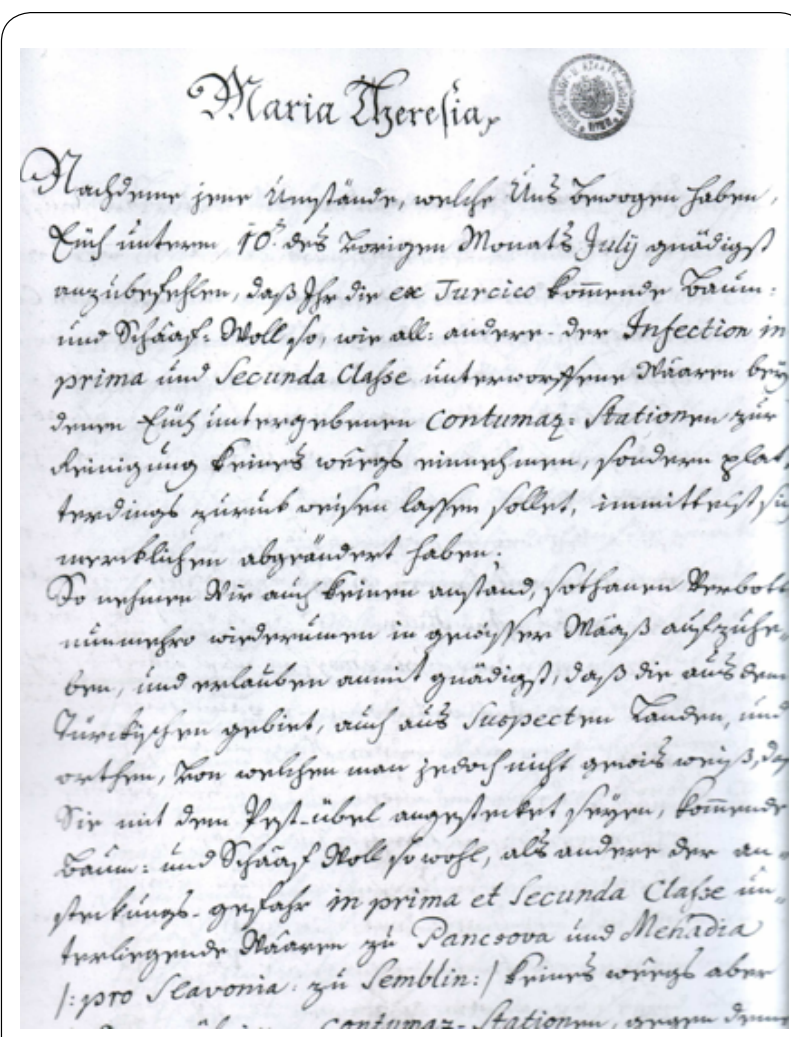

Figure 4: Proclamation of the Empress Maria Theresa about measures against plague epidemics at the border with the Bosnian Pashaluk from 1754, HHStA, Staatskanzlei, Provinzen, Illyrien, Kart. 1, Fasz. ad 1753 (1-192), Fol. 118
Military Frontier, violating sanitary regulations, because the Ottoman side of the border was dominated by the plague infection. The situation was particularly dramatic in 1766 . On 29 November, Empress Maria Theresa sent a strict order to the Croatian Ban to take maximum precautionary measures for the possible spread of the plague epidemic from Bosnia, before she had already learned that the plague infection was spreading across Bihac and Novi ("über Bihacz herwers bis Novi bereits vorgreifenden Pest-Übel..."). ${ }^{10}$

Throughout the next decades there was significant decrease in the number of plague cases at the border. Until the end of the century, different measures helped in further successful confrontation with the plague epidemic from the side of the Habsburg Empire (for example, in the context of burials, ie prevention of inadequate burials). ${ }^{14}$ On the other hand, the perception of plague was not changed among the Ottomans, and the epidemics ravaged around south-eastern Europe deep into the $19^{\text {th }}$ century.

\section{CONCLUSION}

Besides some short-term setbacks, the Austrian sanitary cordon fulfilled its primary task in great extent throughout the $18^{\text {th }}$ century. Success in dealing with the epidemics of plague and total elimination of the disease at the area of Habsburg lands assured the Austrian court in orientation towards further implementation of modern scientific measures in facing with the challenges of medicine. Of course, it was still impossible for medicine of that period to isolate bacterium Yersinia pestis as a cause of disease. ${ }^{13}$ The development in medicine and optics for such level of perception and analysis was not achieved before the very end of $19^{\text {th }}$ century. However, it was exactly this success around the border that implied huge scientific breakthrough in the development of medicine in Vienna during last several decade of 18 th century, and especially helped to foster brave scientific experiments in the decade of rule of the Emperor Joseph II (1780-1790). Efforts of Joseph II have been crowned with the construction of a large hospital in Vienna, (Allgemeines Krankenhaus), which was opened in $1784{ }^{15}$ Through the building of this institution, Vienna paved its way towards dominance in the medical field during next century. 


\section{REFERENCES}

1. Hrabak B. Kužne radnje u Bosni i Hercegovini 14631800 [Plague Epidemics in Bosnia and Herzegovina 1463-180o]. Istorijski zbornik 2, Banja Luka, 1981; 5-43. Serbian.

2. Österreichisches Staatsarchiv, Abteilung Haus-, Hofund Staatsarchiv [Austrian State Archive, Department House, Court and State Archive, further on: HHStA], Staatenabteilungen, Illyrico-Serbica, Kart. 1: 16111738, Fasz. Illyrico-Serbica K1/Konv. B, 1-431, Fol. 35-39.

3. Džaja S. M. Politički i logistički okvir prodora Eugena Savoyskog do Sarajeva 1697. godine [The Political and Logistical Framework of the Penetration of Prince Eugene of Savoy to Sarajevo in 1697], in Srećko M. Džaja, Eseji, razgovori, polemike, prijevodi [], München 2005, p. 87. Croatian.

4. Panzac D. Quarantaines et lazarets. L'Europe et la peste d'Orient (XVIIe-XXe siècles) [Quarantine and Lazarets. Europe and the Oriental plague (17th-2oth Centuries)], Aix-en-Provence 1986. French

5. Roksandić D. Posavska krajina/granica od 1718. do 1739. godine [Border on River Sava 1738-1739], Ekonomska i ekohistorija, Vol. III, broj 3 (Zagreb 2007), p. 62-82. Croatian.

6. Lesky E. Die österreichische Pestfront an der k.k. Militärgrenze [Austrian Front Against Plague on Military Border], Saeculum 8 (Wien 1957), p. 82-105. German.

7. HHStA, Staatenabteilungen, Ragusa, Kart. 3: 17211807, Fasz. 3 A a) Concepte 1721-1804, Copien 17841802, Fol. 5-29.

8. Panzac D. La peste dans l'Empire Ottoman 1700-1850 [The Plague in the Ottoman Empire 1700-1850], Leuven 1985. French.
9. Lašvanin N. Ljetopis [Chronicle]. Ed. by Gavran I, Sarajevo 1981. Croatian.

10. Gavrilović S. Građa za istoriju vojne granice u XVIII veku. Knjiga II: Banska krajina XVII-XVIII vek [Documents for the History of Military Border in the 18th century. Book II: The Border in Banska Krajina 17th18th Centuries]. Sanu, Zbornik za istoriju, jezik i književnost srpskog naroda, II odeljenje - spomenici na tuđim jezicima. Knjiga XXXIV, Beograd 1997. Serbian.

11. Dabić VS. Banska krajina, 1688-1751. Prilog istoriji srpskog i hrvatskog naroda i krajiškog uređenja u Baniji [Banska krajina, 1688-1751. A Contribution to the History of the Serbian and Croat People and the Border Organization in Banija]. Beograd-Zagreb, 1984. Serbian.

12. HHStA, Staatskanzlei, Provinzen, Illyrien, Kart. 1, Fasz. ad 1753, Fol. 118-121.

13. Bramanti B, Dean KR, Walløe L, Chr. Stenseth N. 2019 The Third Plague Pandemic in Europe. Proc. R. Soc. B 286: 20182429. http://dx.doi.org/10.1098/ rspb.2018.2429

14. Vasin G, Božanić S, Kisić Božanić M. Neadekvatno sahranjivanje kao važan faktor u epidemijama kuge kod Srba u Habzburškoj monarhiji krajem 18. veka - istorijska analiza [Inadequate Burial as an Important Factor in Plague Epidemics among Serbs in the Habsburg Monarchy at the End of the 18th Century - Historical Analysis]. Srp Arh Celok Lek 2014, NovDec, 142 (11-12): 764-7. Serbian.

15. Bernard P. P. The Limits of Absolutism: Joseph II and the Allgemeines Krankenhaus, Eighteenth-Century Studies, 1975, 9(2): 193-215. 